\title{
Resettlement Policy for Communities Affected by Natural Disaster in South Lampung Regency
}

\author{
Thio Haikal Anugerah ${ }^{1}$, Muhammad Akib ${ }^{2}$, H.S. Tisnanta ${ }^{3}$ \\ \{thio.haika197@gmail.com ${ }^{1}$, akib97@yahoo.co.id ${ }^{2}$, eronymus.soerjatisnanta@fh.unila.ac.id ${ }^{3}$ \} \\ Faculty of Law, Lampung University, Indonesia ${ }^{1}$, Faculty of Law, Lampung University, Indonesia ${ }^{2}$, \\ Faculty of Law, Lampung University, Indonesia ${ }^{3}$
}

\begin{abstract}
Resettlement in the context of disaster management is a policy that has a broad impact on the affected community on legal, social and economic aspects. This article focuses on problems in implementing the resettlement policy for victims of the tsunami in South Lampung which occurred in December 2018. By using the socio-legal approach, the results of the study indicate that the resettlement policy for communities affected by the tsunami in South Lampung was carried out based on the Regent Decree No. B/613.1/VI.02/HK/2019. This policy was carried out as an effort to recover from the tsunami that occurred. In its implementation, this policy has an impact on at least three aspects of the life of the community concerned, namely the legal impact, social impact and economic impact both before, during the process, and after the construction of new housing.
\end{abstract}

Keywords: Resettlement, Natural Disaster, South Lampung

\section{Introduction}

The Sunda Strait Tsunami disaster that occurred at the end of 2018 has left enormous grief and loss for the Indonesian people. According to Eduardo Rodriguez-Oreggia, natural disasters have an impact on two things, namely physical impacts and social impacts [1]. He further said that there is a positive correlation between natural disasters and increased socioeconomic vulnerability in a family or community, where this vulnerability ultimately makes the recovery process for the disaster even more difficult. In the tsunami disaster in South Lampung, it was recorded that at least 426 people died, 7,202 were injured, and 23 people were declared missing [2]. From an economic perspective, the tsunami disaster caused losses of more than 200 billion rupiah [3]. Responding to this problem, the government as a stakeholder should take action in order to minimize potential losses due to this natural disaster.

With regard to disaster management, the Indonesian state actually has a legal instrument in the form of Law Number 24 of 2007 concerning Disaster Management. Where it is stated in the law that disaster management is the responsibility of the government and local governments. In addition, it is also stated in the regulation that disaster management is carried out on the basis of humanity, justice, equality in law and government, balance, harmony and harmony, legal order and certainty, togetherness, environmental preservation, and science and technology, which means that its implementation presupposes holistic disaster management. 
Returning to the tsunami issue as previously described, there were 6,999 people who were forced to flee due to the natural disaster of the tsunami [4]. Responding to this problem, the local government of South Lampung Regency has implemented a resettlement or resettlement policy. During the resettlement process, people affected by the disaster were temporarily asked to live in shelters (temporary housing). By cooperating with several parties such as mass organizations and the TNI, the South Lampung Regional Government has prepared 537 shelters [5].

With regard to this resettlement policy, Jamie Draper and Catriona Mckinnon[6] stated that in carrying out the resettlement policy, there are at least two stages that must be considered, namely the decision-making stage and the implementation stage. At the decisionmaking stage, the participation of the parties who will be affected by the policy is a core element that ethically must be realized. Meanwhile, at the implementation stage, it is important to pay attention to the provision of needs, resources and services that need to be provided to affected parties. In essence, this resettlement policy is a momentum for the welfare of parties affected by natural disasters, aka not just restoring what once existed, but making people live in a much better condition.

\section{Methods}

Based on this background, this paper is intended to examine the resettlement policy held for parties affected by natural disasters in South Lampung. This study seeks to examine the implementation of the resettlement policy for those affected by the tsunami disaster in South Lampung by analyzing whether the resettlement policy was implemented by considering the legal, economic, social, cultural, and human rights aspects of the parties affected by the tsunami disaster. This research is a legal research that uses an approach in which a policy is studied not only in terms of text, but also a deepening of the context that includes all processes, from the formation of laws to the operation of laws [7].

\section{Result and discussion}

\section{Resettlement policy for tsunami-affected communities in South Lampung}

The natural disaster of the Sunda Strait tsunami that occurred at the end of 2018 made the Regional Government of South Lampung Regency as the organizer of the government in the area to take disaster management measures. According to Law Number 24 of 2007 concerning Disaster Management, it is stated that the implementation of disaster management includes three parts, namely pre-disaster, emergency response, and post-disaster. Where there is a paradigm shift in disaster management with the existing laws, which only emphasized issues of emergency response.[8]

In the pre-disaster section, disaster management is carried out before the occurrence or occurrence of a disaster, while in the emergency response section and the post-disaster section, it is the implementation of disaster management carried out after a disaster occurs. In its implementation, the implementation of disaster management consists of a series of policy aimed at disaster management, where in the context of tsunami disaster management in South Lampung, actions or steps that have been taken by the South Lampung Regional Government are one of them by establishing a resettlement policy for victims who were affected or affected by the tsunami.[9] The resettlement policy referred to here is a policy of building permanent 
or permanent housing in a new place for all communities affected by the tsunami in South Lampung due to the destruction or damage to their previous dwellings.

According to the Collins Dictionary, the definition of resettlement is the process of moving a group of people to another place due to conditions that make it impossible for these people to remain in the area where they once lived.[10] If examined further, it can be seen that this resettlement policy is an embodiment of one of the specific strategies in the 2015-2019 National Disaster Management Plan with a vision to build back better and safer or built back better and safer. Where this particular strategy emphasizes on better and safer community living conditions after the post-disaster recovery process. Even though, this policy is in a postdisaster framework or stage, in its implementation it is related to the emergency response stage or phase.

With regard to the implementation of disaster management at the emergency response level, the implementation includes: quick and precise assessment of location, damage and resources; determining the status of a disaster emergency, rescuing and evacuating the affected community; fulfillment of basic needs; protection for vulnerable groups; and the immediate restoration of vital infrastructure and facilities. On the other hand, at the postdisaster level, the implementation of disaster management includes: rehabilitation and reconstruction. Where rehabilitation consists of a series of activities which include: improving the environment in the disaster area; repair of public infrastructure and facilities; providing assistance for community housing repairs; psychological social recovery; health services; reconciliation and conflict resolution; social, economic and cultural recovery; restoration of security and order; restoration of government functions; and restoration of public service functions. Meanwhile, reconstruction consists of a series of activities covering: reconstruction of infrastructure and facilities; rebuilding of community social facilities; revival of community socio-cultural life; application of appropriate design and use of better and disaster-resistant equipment; participation and participation of social institutions and organizations, the business world and the community; improvement of social, economic and cultural conditions; increasing the function of public services; or improvement of primary services in society.

In practice in the field, implementation of the resettlement policy takes a long time, and in that long span of time the government and related parties assume responsibility for meeting the necessary needs of victims of natural disasters. Jamie Draper and Catriona Mckinnon[6] stated that in implementing the resettlement policy, there are two important stages that need to be considered, namely the decision-making stage and the implementation stage. At this stage of decision making regarding resettlement policies, things that need to be considered are community participation, social aspects, economic aspects, legal aspects, and cultural aspects. On the other hand, at the implementation or implementation stage, things that must be considered for policy administrators are the fulfillment of basic needs for affected parties as long as the occupancy remains unoccupied. For more details, please look at the flow chart below: 

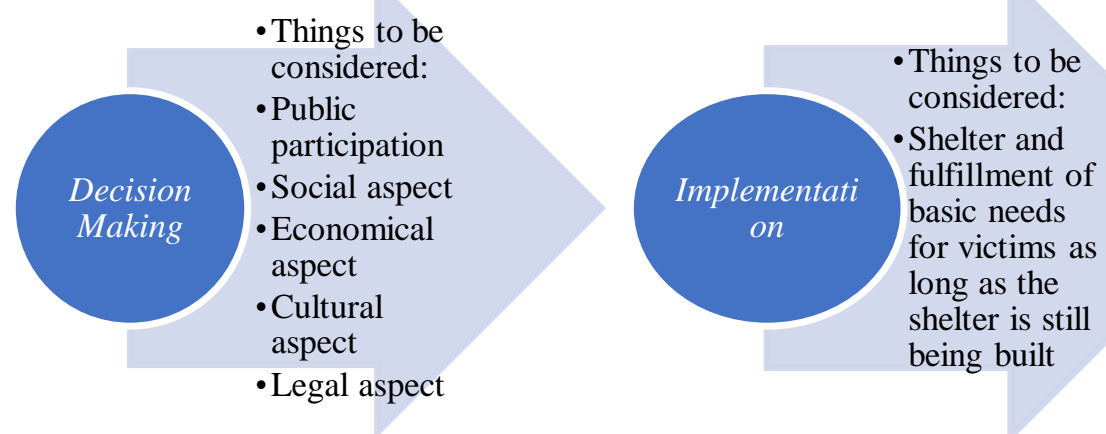

Figure 1. Resettlement Policy within Disaster Management Framework

At the decision making stage, community participation is a crucial matter that must be considered by the government. This is because this policy is essentially intended for the people affected by the disaster, so that the government as the organizer of the policy should invite these people to participate in implementing this policy. Community participation is carried out based on five principles, namely: Participants are representatives of the population; emphasis is placed on understanding the issue at hand and the entirety of their significances; a range of values and points are taken into consideration; consensus and common ground are sought; and policy and decision-making are influenced from the ground up [11]. Public participation in this resettlement policy can be pursued through a series of activities, namely: providing information to disaster-affected communities regarding this policy, listening to responses and opinions of disaster-affected communities on resettlement policies, the government and the community looking for solutions to problems related to resettlement policies, and conical on the agreements between the government and the people affected by this policy [12]. In addition, in community participation, another important factor that determines the success of a policy is its relation to the public policy communication process. Good communication will undoubtedly produce good responses from the public who are the targets of the policy.

With regard to social, economic and cultural aspects at the stage of decision making in the resettlement policy, this is closely related to the need to conduct a social impact assessment by the policy administrator which is generally called a social impact assessment (SIA). Social Impact Assessment according to Frank Vanclay is an analysis process (which predicts, evaluates, and reflects) and overcomes the consequences that arise, whether desired or undesirable in the community environment which is the object of planning (both in a policy and projects) or other social changes that arise in the process in order to create a sustainable and just community environment [13]. Broadly speaking, SIA consists of four stages, namely scoping, forecasting impact, mitigation, and evaluation and monitoring.

At the scoping stage, there are three aspects that need to be considered, namely the identification of the main issues that form the basis for determining the affected components. The second aspect is determining the area to be studied, and the third aspect is an estimate of how long the impact will last [14]. At the impact prediction stage, there are also three aspects that need to be studied, namely, who is affected, what kind of impact will it take, and how long it will last [14]. Furthermore, at the mitigation stage, the impacts that have been assessed in the previous stage are examined whether mitigation measures can be taken for these impacts. In the last stage, an evaluation or assessment of the existing impacts of all alternative 
locations that will be used for resettlement development is carried out and assesses whether the specified mitigation design is appropriate and monitors whether its implementation is effective and efficient [14]. In the study of the social impact or SIA, this consideration of the social, economic and cultural aspects of the affected community will be analyzed in depth, so that in the process a better quality of life is created for the people affected by the disaster when they inhabit their new settlements.

Finally, with regard to legal aspects, generally this relates to what legal instruments are used, and the scope of authority. In the context of resettlement policy, although this policy is based on a series of disaster management measures. However, the implementation of this policy has links to other legal regimes, such as the spatial planning legal regime and the regional government legal regime. At the implementation stage, things that need to be considered besides the implementation of resettlement are the fulfillment of basic needs for people affected by natural disasters as well as temporary housing for them to occupy while the resettlement has not been completed.

Based on the discussion described in the previous section, the resettlement policy for tsunami-affected communities in South Lampung can be analyzed in two parts or points of view, namely in the decision-making section, and in the implementation or implementation of the resettlement policy itself. In the decision-making section, it will be examined whether the resettlement policy in the tsunami-affected communities in South Lampung involves community participation or not, whether this resettlement is carried out by considering the economic, social, and cultural aspects of the tsunami-affected community in the future, and what legal instruments are used. in carrying out this policy. Furthermore, at the implementation stage, it will be examined whether the resettlement policy for the community affected by the tsunami in South Lampung was met with their basic needs during the resettlement policy process.

The resettlement policy for communities affected by the tsunami in South Lampung was carried out based on Regent Decree No. B/613.1/VI.02/HK/2019, with regard to decision making, in the aspect of public participation regarding resettlement policies in communities affected by the tsunami disaster in South Lampung, the regional government of South Lampung only carried out a part of the entire series of public or community participation as described in the previous discussion. The Regional Government of South Lampung only provided information that there would be construction of permanent housing for some of the residents affected by the tsunami disaster.

Then with regard to legal aspects, as we know that law as the basis for implementing policies is necessary for the people to carry out the arrangement of state life, and organizing various interests of a legal product is important so that there is no collision of interests.[15] The regional government of South Lampung district in response to the natural disaster of the tsunami that occurred at the end of 2018, at the normative level, has issued at least 17 Regent Decrees and 1 Regent Regulation issued in response to the disaster.

Furthermore, in terms of considering social, economic and cultural aspects, in implementing the resettlement policy for the communities affected by the tsunami disaster in South Lampung, the organizers claimed to have conducted a study but whether the policy had carefully considered the social, economic and cultural aspects of the affected community The disaster in their new residence cannot be ascertained until now. This is for at least two reasons. The first reason is the unclear or transparent results of studies conducted by the organizers. The second reason is that the resettlement development progress has only just begun and has not yet been completed. So that the effectiveness of the new residence has not been tested. 
At the implementation level or at a practical level, the Regional Government of South Lampung Regency has carried out a series of disaster management measures in an emergency response, starting from the evacuation of tsunami victims to the construction of temporary shelters. For tsunami victims whose houses were badly damaged, the South Lampung Regency Government implemented a resettlement policy and prohibited the victims from rebuilding their houses in their original places [16].

While the resettlement process for new housing for tsunami victims has not been completed, the Regional Government of South Lampung Regency has been asked to stay temporarily in temporary housing. The problem is, regarding the information on how long they will stay in shelters, and when they can occupy the shelter, it remains unclear. Especially because permanent housing will be built in the area that is used as a shelter, the victims are confused about where they will stay during the construction of permanent housing.[17] This indicates that there is inadequate planning and that victims are not involved in participating in the policy.

Further problems later, in implementing this policy, there are new problems such as the absence of land assets, [18] and others [19]. Not to mention, because the resettlement process was carried out in stages for local people who were still waiting for their turn to build Hun tap, they had to live in shelters that were in poor condition. Such as inadequate public bathrooms, and temporary shelters that do not have titters so that water floods in when it rains which results in flooding in the shelter area. Some tsunami victims even admit that they did not receive any assistance at all, because coincidentally they were not recorded [20].

\section{References}

[1] E. Rodriguez-Oreggia, A. de la Fuente, R. de la Torre, and H. A. Moreno, "Natural Disasters, Human Development and Poverty at the Municipal Level in Mexico," J. Dev. Stud., 2013, doi: 10.1080/00220388.2012.700398.

[2] "Update Tsunami Selat Sunda 426 orang Meninggal Dunia, 7202 luka-luka," 2018. https://nasional.kompas.com/read/2018/12/28/15102481/update-tsunami-selat-sunda-426-orangmeninggal-dunia-7202-luka-luka-dan-23 (accessed Jun. 25, 2020).

[3] "Hitungan Sementara Kerugian Akibat Tsunami Selat Sunda Capai Rp.202 M," 2019. https://www.tribunnews.com/regional/2019/01/16/berdasarkan-hitungan-sementara-kerugianakibat-tsunami-selat-sunda-capai-rp-202-m (accessed Jun. 25, 2020).

[4] "Infografis Badan Nasional Penanggulangan Bencana," 2019. https://bnpb.go.id/uploads/24/2019-01-22-infografis-selat-sunda-1.jpg (accessed Jun. 25, 2020).

[5] "Pemkab Lamsel Siapkan 537 Unit Hunian Sementara Korban Bencana," 2019. https://www.lampost.co/berita-pemkab-lamsel-siapkan-537-unit-hunian-sementara-korbanbencana.html (accessed Jun. 25, 2020).

[6] J. Draper and C. McKinnon, "The ethics of climate-induced community displacement and resettlement," Wiley Interdiscip. Rev. Clim. Chang., 2018, doi: 10.1002/wcc.519.

[7] H. P. Wiratraman, "Penelitian Socio-Legal dan Konsekuensi Metodologisnya," 2000. https://herlambangperdana.files.wordpress.com/2008/06/penelitian-sosio-legal-dalam-tun.pdf.

[8] B. D. Anggono, "Harmonisasi Peraturan Perundang-undangan di Bidang Penanggulangan Bencana," J. Mimb. Huk. Fak. Huk. Univ. Gadjah Mada, vol. 22, no. 2, p. 1, 2012, [Online]. Available:

http://mimbar.hukum.ugm.ac.id/index.php/jmh/article/view/295\%0Ahttp://mimbar.hukum.ugm. ac.id/index.php/jmh/article/download/295/150.

[9] "Pemerintah Segera Bangun Rumah Untuk Korban Tsunami Di Lamsel," 2019. https://tirto.id/pemerintah-segera-bangun-rumah-untuk-korban-tsunami-di-lamsel-dfjU (accessed Jun. 26, 2020).

[10] "Resettlement," 2020. https://www.collinsdictionary.com/dictionary/english/resettlement 
(accessed Jun. 26, 2020).

[11] T. Berman, Public participation as a tool for integrating local knowledge into spatial planning: Planning, participation, and knowledge. 2016.

[12] J. L. Creighton, "The public participation handbook: making better decisions through citizen involvement," J. Ratchasuda Coll. Res. Dev. Pers. With Disabil., 2005.

[13] H. A. Becker and F. Vanclay, The international handbook of social impact assessment: Conceptual and methodological advances. 2003.

[14] Dyah and G. Pratiwi, "Penerapan Metode Social Impact Assessment dalam Pelaksanaan Tanggung Jawab Sosial Perusahaan ( Studi Kasus Pelaksanaan CSR di Artha Graha Peduli ) Penerapan Metode Social Impact Assessment dalam Pelaksanaan Tanggung Jawab Sosial Perusahaan," Indonesia University, 2012.

[15] S. Oktapani, "RAKYAT INDONESIA BERDASARKAN UU SJSN DAN UNDANGUNDANG BPJS POLITICS OF LAW THE FULFILLMENT OF THE RIGHT TO HEALTH FOR THE INDONESIAN PEOPLE BASED ON THE," vol. 8, no. 1, 2020.

[16] "Geliat Kehidupan Warga Lampung Selatan Pasca Tsunami Selat Sunda," 2019. https://regional.kompas.com/read/2019/03/18/11050521/geliat-kehidupan-warga-lampungselatan-pasca-tsunami-selat-sunda?page=all (accessed Jun. 26, 2020).

[17] "Huntara di Desa Kunjir Mulai Dibongkar," 2020. https://www.lampost.co/berita-huntara-didesa-kunjir-mulai-dibongkar.html (accessed Jul. 10, 2020).

[18] "Tak Punya Aset, Pemkab Kesulitan Bangun Huntara," 2019. http://www.radarlamsel.com/takpunya-aset-pemkab-kesulitan-bangun-huntara (accessed Jun. 25, 2020).

[19] "Penyintas Tsunami di Sukaraja Lamsel Minta Tambahan Sanitasi," 2019. https://www.cendananews.com/2019/04/penyintas-tsunami-di-huntara-sukaraja-lamsel-mintatambahan-sanitasi.html (accessed Jul. 10, 2020).

[20] "Warga Diminta Tetap Menempati Huntara Di Waymuli Timur," 2020. https://www.lampost.co/berita-warga-diminta-tetap-menempati-huntara-di-way-muli-timur.html (accessed Jul. 10, 2020). 